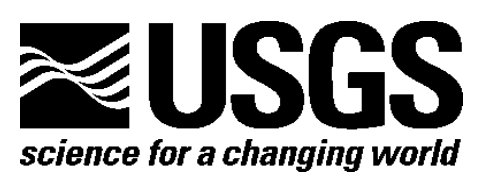

Prepared in cooperation with the U.S. Army, Fort Irwin National Training Center

\title{
Geology and Geophysics Applied to Groundwater Hydrology at Fort Irwin, California
}

David C. Buesch, Editor

Open-File Report 2013-1024

U.S. Department of the Interior

U.S. Geological Survey 
Geology and Geophysics Applied to Groundwater Hydrology at Fort Irwin, California

David C. Buesch, Editor

\section{Introduction to the Geologic and Geophysical Studies of Fort Irwin, California}

By David C. Buesch

Open-File Report 2013-1024-A

U.S. Department of the Interior

U.S. Geological Survey 


\section{U.S. Department of the Interior \\ SALLY JEWELL, Secretary}

\section{U.S. Geological Survey \\ Suzette M. Kimball, Acting Director}

U.S. Geological Survey, Reston, Virginia: 2014

For more information on the USGS—-the Federal source for science about the Earth,

its natural and living resources, natural hazards, and the environment-visit

http://www.usgs.gov or call 1-888-ASK-USGS (1-888-275-8747)

For an overview of USGS information products, including maps, imagery, and publications, visit http://www.usgs.gov/pubprod

To order this and other USGS information products, visit http://store.usgs.gov

Any use of trade, firm, or product names is for descriptive purposes only and does not imply endorsement by the U.S. Government.

Although this information product, for the most part, is in the public domain, it also may contain copyrighted materials as noted in the text. Permission to reproduce copyrighted items must be secured from the copyright owner.

Suggested citation: Buesch, D.C., 2014, Introduction to the geologic and geophysical studies of Fort Irwin, California, chap. A of Buesch, D.C., ed., Geology and geophysics applied to groundwater hydrology at Fort Irwin, California: U.S. Geological Survey Open-File Report 2013-1024, 8 p., http://dx.doi.org/10.3133/ofr20131024A. 


\section{Contents}

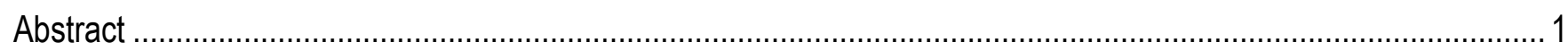

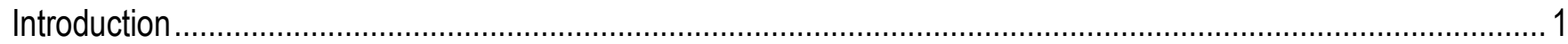

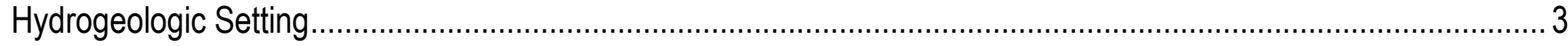

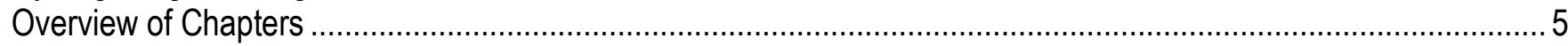

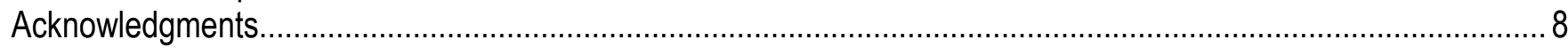

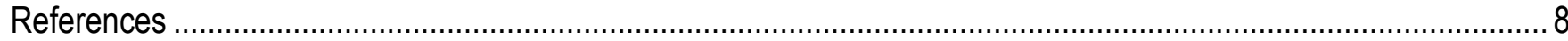

\section{Figures}

1. Location map of Fort Irwin, California, with insert map of the Mojave Desert. .......................................... 2

2. Map of groundwater basins of the Fort Irwin area, California............................................................ 4

\section{Tables}

1. Table of groundwater basin names in the Fort Irwin area in 1975 and 2012 ........................................ 


\title{
Introduction to the Geologic and Geophysical Studies of Fort Irwin, California
}

\author{
By David C. Buesch
}

\begin{abstract}
Geologic and geophysical investigations in the vicinity of Fort Irwin National Training Center, California, have been completed in support of groundwater investigations, and are presented in eight chapters of this report. A generalized surficial geologic map along with field and borehole investigations conducted during 2010-11 provide a lithostratigraphic and structural framework for the area during the Cenozoic. Electromagnetic properties of resistivity were measured in the laboratory on hand and core samples, and compared to borehole geophysical resistivity data. These data were used in conjunction with ground-based time-domain and airborne data and interpretations to provide a framework for the shallow lithologic units and structure. Gravity and aeromagnetic maps cover areas $\sim 4$ to 5 times that of Fort Irwin. Each chapter includes hydrogeologic applications of the data or model results.
\end{abstract}

\section{Introduction}

Eight geologic and geophysical investigations were completed for this report on the U.S Army Fort Irwin National Training Center, California. These investigations provide constraints on the geologic framework of the area, guide groundwater-resources exploration, and provide input for the development of hydrogeologic models. These investigations include (1) the compilation and evaluation of surficial geologic maps, (2) lithostratigraphic studies based on recent mapping and recently drilled boreholes, (3) three different scales of electromagnetic studies from core and hand samples to groundbased and airborne data, (4) ground-based and airborne gravity data, and (5) aeromagnetic data. This introductory chapter provides a short geologic and hydrogeologic overview of these studies.

Fort Irwin National Training Center (herein referred to as Fort Irwin) encompasses an area of $\sim 2,770 \mathrm{~km}^{2}$. The main center of buildings that supports operations at Fort Irwin (referred to as the garrison) is located $\sim 50 \mathrm{~km}$ northeast of the city of Barstow (fig. 1). Fort Irwin is a critical training center for the Army's desert operations and requires water for thousands of personnel year-round. Fort Irwin is located in the north central part of the Mojave Desert, a geologically complex structural block that is bounded on the southwest by the San Andreas Fault and on the northwest by the Garlock Fault (fig. 1). Within this block, Fort Irwin is located in a region of north-south trending faults that collectively are referred to as the Eastern California Shear Zone. The Fort Irwin area is a region of numerous mountain ranges and broad to isolated alluvial valleys. Many valleys contain dry lakes or playas. Local geographic and study-specific features, including sample and borehole locations, are described in individual chapters. 


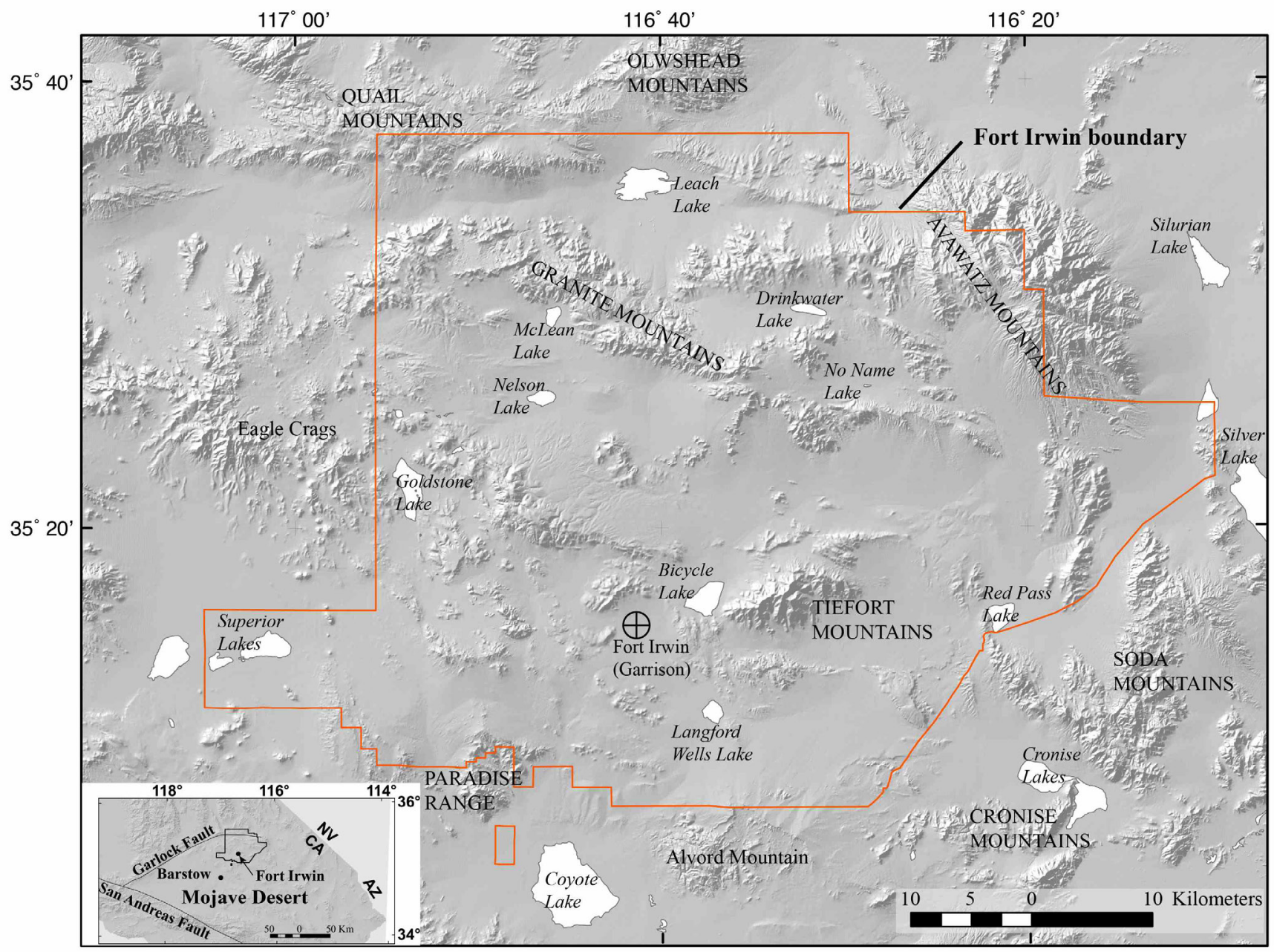

Figure 1. Location map of Fort Irwin, California, with insert map of the Mojave Desert.

In various publications and internal documents, Fort Irwin is referred to as the (1) Fort Irwin National Training Center, (2) National Training Center, Fort Irwin, (3) National Training Center (or even just NTC), or simply as (4) Fort Irwin, and it is even informally referred to as "the base". This Open-File Report has been compiled in support of the investigations by the U.S. Geological Survey (USGS) with cooperative funding and logistical support from the U.S Army. The authors for various chapters have different connections with the U.S. Army, departments at Fort Irwin, or investigating agencies such as the USGS, so how authors refer to Fort Irwin in their respective chapters varies.

The majority of data in all chapters are based on Système International (SI) units; for example, map distances, thickness of units, elevation, relief, grain sizes in rocks, and resistivity, gravity, and magnetic properties. Some data such as depth of samples and geophysical logs in boreholes were originally collected in feet; therefore, these data retain the original units. Because the ground-based, time-domain electromagnetic (TEM) soundings (and ultimately the modeling) are compared to borehole data, the depths in this chapter also are presented primarily in feet; however, plots of the TEM model data are presented in both feet and metric values. Water flow is the other measurement that is collected and presented in English units of gallons per minute (gal/min). 


\section{Hydrogeologic Setting}

Although the focus of this report is on geological and geophysical data and their interpretation, one of the primary uses of these data will be hydrogeologic and groundwater investigations. There are 13 groundwater basins and subbasins that lie entirely or partly within the boundary of Fort Irwin (fig. 2). Groundwater basins and subbasins are defined as alluvial aquifers or a stacked series of alluvial aquifers with reasonably well-defined boundaries in a lateral direction and a definable bottom (California Department of Water Resources, 2003). Furthermore, the mapped boundaries of these basins are nonwater-bearing deposits such as rock or sediments with very low permeability, or a geologic structure such as a fault. The emphasis on alluvial basins is the primary reason why, in the Fort Irwin area, groundwater basin boundaries (fig. 2) are inferred to coincide with the contact of alluvium with plutonic and metamorphic rocks and locally, exposures of Miocene volcanic rocks (compare with the map in Miller and others, chap. B in this report). Locally, groundwater basin boundaries are along low-lying topographic and drainage divides, some of which are simplified as straight-line boundaries between exposures of plutonic, metamorphic, or Miocene volcanic and sedimentary rocks (Kjos and others, 2014).

In the Fort Irwin area, the California Department of Water Resources (2003) identified 10 basins, with one basin subdivided into 2 subbasins. However, as more detailed and recent groundwater investigations progressed, 2 additional basins have been divided into 2 subbasins each, with the net result that there are a total of 13 basins and subbasins (table 1; Jill Densmore, USGS California Water Science Center, written commun., August 2012). The naming convention for groundwater basins and subbasins established by California Department of Water Resources $(1975 ; 2003)$ is to have either a proper (capitalized) location name coupled with Groundwater Basin or a location name coupled with Subbasin. For example, Langford Valley Groundwater Basin (California Department of Water Resources, 1975) was divided into the Langford Well Lake Subbasin and the Irwin Subbasin (California Department of Water Resources, 2003). However, rather than maintaining or propagating a status of subbasin, the newly-defined subbasins are referred to directly as Basins (Jill Densmore, USGS California Water Science Center, written commun. August 2012; Kjos and others, 2014). Bicycle Valley Groundwater Basin was divided into the Bicycle and Nelson subbasins, and are referred to as Bicycle Basin and Nelson Basin, respectively. Red Pass Valley Groundwater Basin, which includes an area referred to by Fort Irwin personnel as the "Central Corridor" area, was divided into Red Pass Basin on the east and Central Corridor Area Basin in the west. In this report, Avawatz Valley Groundwater Basin is referred to as Drinkwater Basin, following the name used by Fort Irwin personnel which refers to the Drinkwater playa in the northern part. 


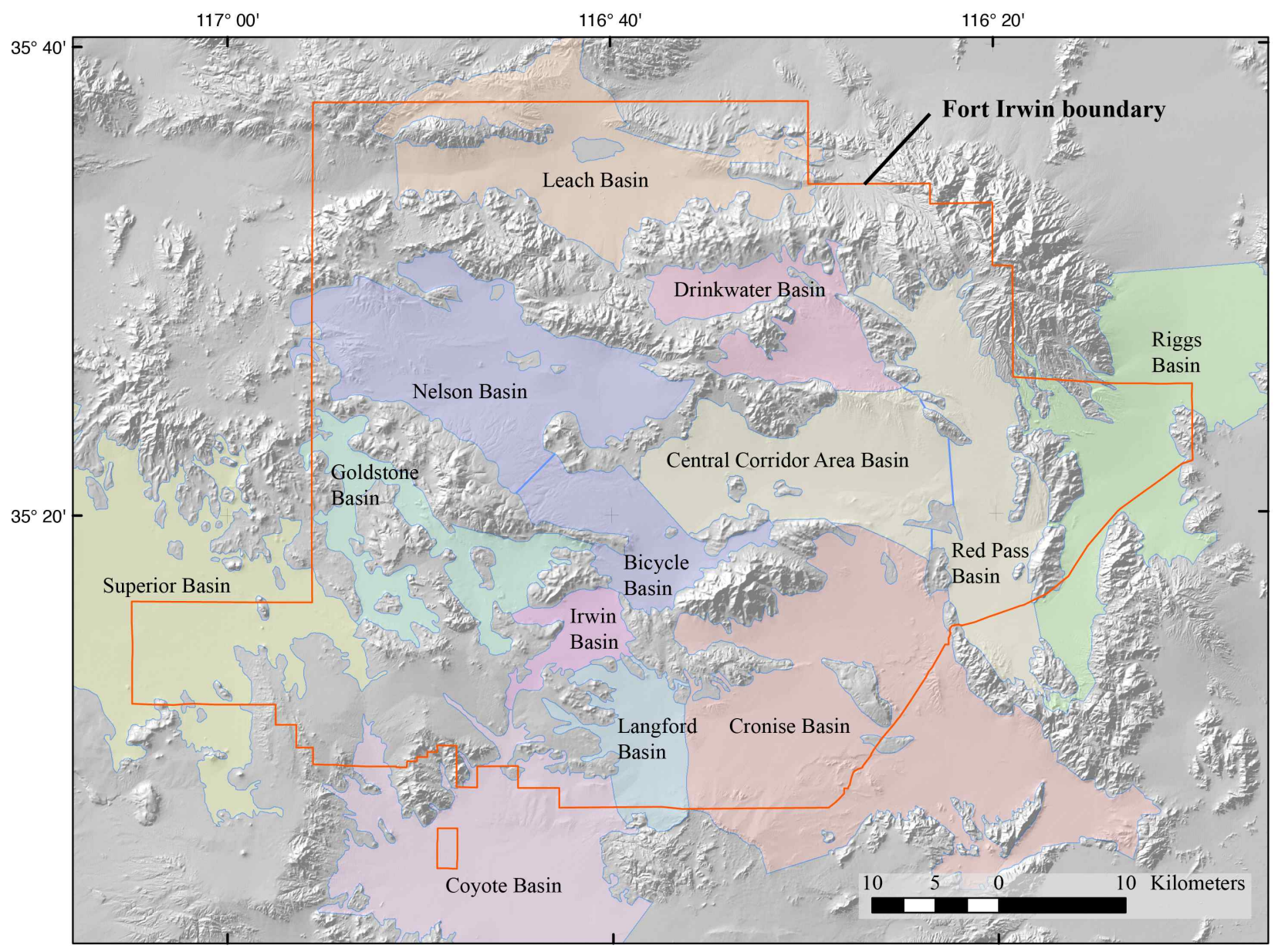

Figure 2. Map of groundwater basins of the Fort Irwin area, California. Blue wide lines are the divides where Bicycle Valley Groundwater Basin was subdivided into the Bicycle and Nelson Basins, and Red Pass Valley Groundwater Basin was subdivided into Red Pass and Central Corridor Area Basins. 
Table 1. Table of groundwater basin names in the Fort Irwin area in 1975 and 2012.

\begin{tabular}{ll}
\hline \multicolumn{1}{c}{ Groundwater Basin (1975) ${ }^{1}$} & \multicolumn{1}{c}{ Groundwater Basin (2003, 2012, 2014) 2,3,4 } \\
\hline Avawatz Valley & Drinkwater $^{5}$ \\
\hline Bicycle Valley & $\begin{array}{l}\text { Bicycle }^{6} \\
\text { Nelson }\end{array}$ \\
\hline Cronise Valley & Cronise \\
\hline Coyote Lake Valley & Coyote \\
\hline Goldstone Valley & Goldstone \\
\hline Langford Valley & $\begin{array}{l}\text { Langford } \\
\text { Irwin }\end{array}$ \\
\hline Leach Valley & Leach \\
\hline Red Pass Valley & $\begin{array}{l}\text { Red Pass } \\
\text { Central Corridor Area }\end{array}$ \\
\hline Riggs Valley & Riggs \\
\hline Superior Valley & Superior \\
\hline${ }^{1}$ California Department of Water Resources (1975). \\
${ }^{2}$ California Department of Water Resources (2003). \\
${ }^{3}$ Jill Densmore (USGS California Water Science Center, written commun. August 2012). \\
${ }^{4}$ Kjos and others (2014). \\
${ }^{5}$ The name Drinkwater is based on the local name of the playa in the northern part of the basin. \\
${ }^{6}$ These subbasins are referred to as basins.
\end{tabular}

\section{Overview of Chapters}

This Open-File Report begins with an overview of the entire report (chap. A). Chapters B and C present the geologic map and the general geologic framework and history of the area, respectively. Chapter D examines the subsurface stratigraphy and borehole geophysical logs, and in chapter E, the resistivity of rock samples are measured in the laboratory. The scale of investigation expands to the ground-based time domain electromagnetic (TEM) data that result in one-dimensional (1D) models of resistivity with depth (chap. F), and then to airborne electromagnetic (AEM) resistivity data that results in 3D models of the Leach Basin area (chap. G). The scale of investigation further expands to encompass the area around Fort Irwin with gravity and aeromagnetic data and maps (chaps. H and I, respectively).

Chapter B presents a 1:100,000 scale, generalized surficial geologic map for the Fort Irwin area. This map is a compilation of three geologic maps, and it is the first geologic map produced specifically for the Fort Irwin area. The map focuses on surficial deposits, with 10 mapped units of possibly Pliocene to Quaternary age, primarily distinguishing between alluvial fan deposits of different ages and soil characteristics. The map also shows 10 substrate materials that range in age from Pliocene to Proterozoic and include partially consolidated sedimentary rocks, felsic and mafic volcanic rocks, siliciclastic and carbonate sedimentary rocks, mafic and two types of felsic plutonic rocks, and two types of metamorphic rocks. Youthful faults, many of which have been active during the Quaternary, are depicted as in other surficial geologic maps; however, two additional types of information on faults are represented. First, blind thrust faults are shown because they are locally important forms of deformation. Second, the sense of separation along a fault is identified, including dextral, oblique (typically dextral-normal with a few dextral-reverse), sinistral, and thrust. 
Chapter C summarizes the Cenozoic history of the Fort Irwin area. This chapter draws on previous literature, several chapters in this report, and new studies. Summary descriptions and distributions are provided for the (1) pre-Tertiary bedrock that includes plutonic, metamorphic, and locally exposed sedimentary rocks, (2) Miocene and possibly Pliocene volcanic and sedimentary rocks, and (3) possibly Pliocene to Quaternary sediments and sedimentary rocks. These rocks are described in the context of the Miocene development of highlands, such as volcanic fields, as well as basin formation. General geometry of faults including location, orientation, and sense of separation are described, culminating with the disruption of the early(?) to middle Miocene geologic features by late Miocene to recent faults associated with the Eastern California Shear Zone.

Chapter D summarizes the lithostratigraphy of eight boreholes drilled in the Goldstone Lake and Nelson Lake basins. Cuttings from boreholes are typically described in terms of grain size, sorting, rounding, and color (Kjos and others, 2014); however, for this chapter, selected cuttings samples are described in the context of the (1) type of rock fragments (plutonic-metamorphic, crystallized volcanic, tuffaceous sediment, and lithic-rich sediment), (2) amount of fragment surfaces that appear broken during drilling versus those that were original or part of the drilled rock, and (3) coatings on lithic fragments that represent the matrix of sedimentary rock disaggregated during drilling. In some tuffaceous deposits, glass in the ash shards or pumice clasts is preserved; however, in many deposits, the glass has been altered to clay minerals, and this alteration occurs primarily in older deposits. Lithostratigraphic features such as the amounts and types of lithic clasts and the type of matrix in sedimentary deposits are correlated to geophysical log data. Differences are documented between the more lithic-rich matrix that typically occurs in the younger sandstone (presumably Quaternary and possibly Pliocene) and the typically more ash shard- and pumice clast-rich (typically altered) matrix in the tuffaceous sandstone, fallout tephra, and ignimbrite in the older part of the section (presumably Miocene). The focus of the study was to identify the contact of Quaternary and Miocene deposits because of the potential hydrogeologic differences in properties; therefore, most data are from depths less than $400 \mathrm{ft}$; however, two boreholes have data to $680 \mathrm{ft}$ and $800 \mathrm{ft}$. All boreholes penetrate the (presumably) Miocene sedimentary and volcanic sections, except for one that penetrates gneissic bedrock.

Chapter E summarizes electrical resistivity data measured in the laboratory (LEM) on surface and borehole samples in the Fort Irwin area. There are 111 samples including unconsolidated sediments, consolidated sandstones and tuffaceous sandstones, welded and nonwelded tuffs, felsic and mafic lava flows, and felsic and mafic plutonic rocks. These measurements help build a property-based framework and enable correlations to the borehole geophysical log data and ground-based time-domain and airborne electromagnetic data (TEM and AEM, respectively). Standard laboratory conditions (including saturated, oven dried, and relative humidity) were used on unconsolidated sediments and rock samples to measure resistivity properties. These conditions were intended to bound those conditions expected of the materials in the natural environment. Samples can be subdivided into (1) moderately conductive younger (Quaternary?) sediments with large amounts of crystallized volcanic clasts and lithic-rich sediment and low clay content, and (2) highly conductive older (Tertiary?) sediments with large amounts of tuffaceous sediment and higher clay content. Resistivity measurements on cores are compared to borehole resistivity log data and TEM sounding models, and show good correlations between these measurement techniques despite the differences in scale.

Chapter F summarizes ground-based, time-domain electromagnetic soundings that were collected at 79 locations in 12 groundwater basins within the Fort Irwin area. TEM soundings and the resultant models produce resistivity profiles that penetrate as much as 1,640 $\mathrm{ft}$ below land surface. The TEM soundings were collected between 2010 and 2012 in areas near boreholes that were drilled or 
proposed for drilling during this same period, and also in areas within basins where no boreholes were proposed. Comparisons of TEM resistivity profiles to borehole resistivity log data indicate reasonably good to good correlations between these two techniques. With the correlations of lithostratigraphic features and units to the borehole resistivity logs, the TEM profiles can approximate lithostratigraphic properties and thereby generalized stratigraphic sequences. Comparisons of groups of TEM profiles show the utility of identifying changes in resistivity properties associated with (1) inferred lithostratigraphic units for determining correlations across the area, and even the (2) possible identification of a fault that transects the TEM array. TEM models did not identify the water table in most areas (especially if the water table was below the Quaternary deposits), but several areas were identified where moderate resistivity (20-35 $\Omega-\mathrm{m})$ is associated with viable amounts of water and flow rates, and these relations contrast with areas where low to very low resistivity (less than $20 \Omega-\mathrm{m}$ ) correlate with low water yield.

Chapter G summarizes airborne electromagnetic and magnetic surveys of Leach Basin. The surveys are in a 46- by 16-km area along the northern part of the Fort Irwin area. A resistivity stratigraphy was developed using (1) geologic maps, (2) ground-based, time-domain electromagnetic soundings, and (3) laboratory resistivity measurements on rock outcrop samples and borehole geophysical logs from nearby basins. AEM resistivity models provide subsurface constraints to more than $200 \mathrm{~m}$ depth and show abrupt changes in earth response across faulted boundaries, reflecting the strong lateral resistivity contrast between igneous rocks that make up the basement complex and unconsolidated basin-fill sediments. Intra-basin faults are also identified, and, to a lesser extent, faults within the igneous basement complex can be traced. The distribution of faults throughout the basin and within the subsurface can thus be directly obtained from the airborne data. The airborne resistivity models have been used to trace hydrostratigraphic units throughout the basin.

Chapter H summarizes a compilation of gravity data augmented by newly acquired groundbased gravity measurements that are then modeled for the distribution of low-density Cenozoic volcanic and sedimentary deposits of Fort Irwin and vicinity. The gravity inversion also provides an estimate of the density distribution in the pre-Cenozoic basement rocks. Constraints on the inversion model of gravity data used to provide thickness of basin fill estimates included borehole information, shallow seismic profiles limited to the Langford basin, and TEM soundings. In most of the Fort Irwin area, Cenozoic deposits of sedimentary and volcanic rocks are no more than $300 \mathrm{~m}$-thick, except in areas west of and in the vicinity of Nelson Lake, west of Superior Lakes, near Coyote Lake, and in laterally small basins at Bicycle Lake and Red Pass Lake.

Chapter I summarizes aeromagnetic data, analysis, and maps of anomalies for Fort Irwin and vicinity. The aeromagnetic data are consist of six detailed surveys that cover most of the Fort Irwin area and a recently flown helicopter-based survey along the northern boundary of the area. These data were merged with the regional aeromagnetic anomaly data of California, and were filtered to map the edges of magnetic rocks in the shallow subsurface. Many of the prominent magnetic anomalies arise from variations in magnetic properties within the pre-Cenozoic basement. Although Tertiary volcanic rocks are magnetic, these rocks may be generally too thin or too highly variable in magnetic properties to produce regionally coherent magnetic anomalies; however, they are responsible for the patterns of shortwavelength magnetic anomalies. The edges of magnetic rock bodies result from lithologic contacts, some of which may be faults. The structures mapped by the magnetic data are used to support interpretations of basin depth derived from gravity data, and to map faults concealed by younger deposits. 


\section{Acknowledgments}

The authors of the reports in this Open-File Report gratefully acknowledge financial support from Fort Irwin. During field work and remote data acquisition at Fort Irwin, logistical support was provided by personnel in the Directorate of Public Works, and safety and downrange access was provided by personnel in Range Control. Although acknowledged in individual chapters, many of the authors in this report benefitted from discussions with and used unpublished data from Jill Densmore, Adam Kjos, Joseph Nawikas, and Anthony Brown (all from the USGS California Water Science Center). Jill Densmore and David Miller provided constsructive reviews that improved the manuscript, and they are greatly appreciated.

\section{References}

California Department of Water Resources, 1975, California's groundwater: California Department of Water Resources Bulletin 118, 135 p.

California Department of Water Resources, 2003, California's groundwater (update): California Department of Water Resources Bulletin 118, 246 p.

Kjos, A.R., Densmore, J.N., Nawikas, J.M., and Brown, A.A., 2014, Construction, water-level, and water-quality data for multiple-well monitoring sites and test wells, Fort Irwin National Training Center, San Bernardino County, California, 2009-12, U.S. Geological Survey Data Series 788, 139 p., https://dx.doi.org/10.3133/ds788. 